\title{
HUBUNGAN DUKUNGAN KELUARGA TERHADAP KUALITAS HIDUP PENDERITA KUSTA KECACATAN TINGKAT 2
}

\author{
CORRELATION BETWEEN FAMILY SUPPORT AGAINST QUALITY OF LIFE OF \\ LEPROSY SUFFERER
}

\author{
Andinta Refitlianti ${ }^{1}$, Muhammad Atoillah Isfandiari ${ }^{2}$ \\ ${ }^{1}$ FKMUA, randinta@rocketmail.com \\ ${ }^{2}$ Departemen Epidemiologi FKM UA, ato_epid@yahoo.co.id \\ Alamat Korespondensi: Departemen Epidemiologi Fakultas Kesehatan Masyarakat \\ Universitas Airlangga, Surabaya, Jawa Timur, Indonesia
}

\begin{abstract}
Family support is necessary to improve the quality of life of leprosy sufferer. This study purposed to identify the correlation between four parts of family support (emotional, assessment, instrumental and informational) from the quality of life of second level disability of leprosy sufferer in UPTD Liponsos Kusta Babat Jerawat Surabaya. The research conducted by using cross sectional design by quantitative approaches. The interview was conducted on 54 second level disability of leprosy sufferer. Subjects were selected by simple random sampling. Depth interviews were conducted to obtain deeper information about the studied variables. The selected variable is family support. Descriptive data analysis test by using cross-tabulation on four parts of family support (emotional, assessment, instrumental and informational) for each domain of quality of life. Data analysis test by using linear regression inference between family support in general against quality of life. The result of interview program at UPTD Liponsos Kusta Babat Jerawat Surabaya showed there isa correlation between four parts of family support with quality of life ( $p$ value 0,001, alfa: 0.05). Then, cross tabulation result of four parts of family support obtained that the low informational support variable is the largest percentage of the domains of quality of life. The conclusion that can be drawn, there is a correlation between family support against quality of life of leprosy sufferer. The second level disability of leprosy sufferer at UPTD Liponsos Kusta Babat Jerawat Surabaya get lack of family support that cause the lower the quality of life gained. Family members of leprosy sufferer and the environments should increase its support for leprosy sufferer. The Improvementof family support must be done by expression of empathy, affection and care to the leprosy sufferer.
\end{abstract}

Keywords : Family Support, Quality of life, leprosy sufferer 


\begin{abstract}
ABSTRAK
Dukungan keluarga diperlukan untuk meningkatkan kualitas hidup pada pasien kusta. Penelitian ini bertujuan mengidentifikasi hubungan antara dukungan keluarga ditinjau dari empat dimensi (emosional, penilaian, instrumental dan informasional) terhadap kualitas hidup penderita kusta kecacatan tingkat 2 di UPTD Liponsos Kusta Babat Jerawat Surabaya. Desain dalam penelitian ini analitik cross sectional. Wawancara dilaksanakan pada 54 penderita kusta kecacatan tingkat 2. Subjek ditarik dari populasi dengan cara simple random sampling. Wawancara mendalam dilakukan untuk mendapatkan informasi yang lebih mendalam tentang variabel - variabel yang diteliti. Variabel bebas penelitian adalah dukungan keluarga. Uji analisa data deskriptif menggunakan tabulasi silang antara empat dimensi (emosional, penilaian, instrumental dan informasional) dukungan keluarga terhadap masing - masing domain kualitas hidup. Uji analisa data inferensi menggunakan uji regresi linier antara dukungan keluarga secara umum terhadap kualitas hidup. Hasil penelitian didapatkan ada hubungan dukungan keluarga terhadap kualitas hidup penderita kusta kecacatan tingkat 2 di UPTD Liponsos Kusta Babat Jerawat Surabaya ( $p$ value 0,001, alfa: 0,05). Hasil tabulasi silang dari empat dukungan keluarga didapatkan variabel dukungan emosional yang rendah memiliki persentase terbesar terhadap domain kualitas hidup. Kesimpulan yang dapat ditarik adalah ada hubungan dukungan keluarga terhadap kualitas hidup penderita kusta kecacatan tingkat 2 di UPTD Liponsos Kusta Babat Jerawat Surabaya. Penderita kusta kecacatan tingkat 2 di UPTD Liponsos Kusta Babat Jerawat Surabaya kurang mendapatkan dukungan keluarga, sehingga kualitas hidup yang didapatkan rendah. Anggota keluarga penderita kusta dan masyarakat sekitar hendaknya meningkatkan dukungannya terhadap penderita kusta.
\end{abstract}

\title{
Kata Kunci: dukungan keluarga, kualitas hidup, penderita kusta
}

\section{PENDAHULUAN}

Keberadaan penyakit kusta atau lepra sangat ditakuti. Penyakit ini disebabkan bakteri mycrobakterium leprae, juga dipicu gizi buruk. Tidak jarang penderitanya dikucilkan bahkan diusir. Hal ini disebabkan masih kurangnya pemahaman terhadap penyakit kusta. Mendengar penyakit kusta atau lepra, mungkin yang terbayang adalah penyakit kutukan yang tidak bisa disembuhkan. Penderitanya pun harus diasingkan (Depkes RI, 2007).

Sepanjang tahun 2013, Kementerian Kesehatan RI mencatat 16.856 kasus kusta baru, dengan angka kecacatan 6,82 per 1.000 .000 penduduk. Angka ini menempatkan Indonesia di peringkat ketiga dunia dengan kasus baru kusta terbanyak setelah India (126.913 kasus) dan Brasil (31.044 kasus). Pada tahun 2014, jumlah kasus baru kusta di Indonesia tercatat 17.025 kasus dan angka kecacatan 9,45 per 100.000 penduduk (Depkes RI, 2015).

Menurut data provinsi di Indonesia tahun 2014, Jawa Timur tercatat sebagai provinsi tertinggi di Indonesia yang memiliki kasus baru kusta sebanyak 4.116 kasus, dengan angka kecatatan 12,83 per 100.000 penduduk (Depkes RI, 2015). Provinsi Jawa Timur merupakan provinsi yang memiliki prevalensi penderita kusta tertinggi pada tahun 2014. Dari 38 kabupaten/kota di Jawa Timur, Surabaya merupakan salah satu Kabupaten/Kota yang menduduki peringkat 9 jumlah penderita kusta terbanyak di Jawa Timur dengan jumlah penderita kusta yang terdeteksi pada tahun 2014 sebanyak 176 orang. Selain itu di Surabaya pada tahun 2014 terdeteksi kasus baru penderita kusta cacat 2 sebanyak 15 orang atau prevalensi sebesar 10\%(Dinkes Provinsi Jawa Timur, 2014).

Masalah psikososial yang timbul pada penderita kusta lebih menonjol dibandingkan masalah medis itu sendiri.Hal ini disebabkan oleh adanya stigma dan leprofobi yang banyak dipengaruhi oleh berbagai paham dan informasi yang keliru mengenai penyakit kusta.Sikap dan perilaku masyarakat yang negatf terhadap penderita kusta seringkali menyebabkan penderita kusta merasa tidak mendapat 
tempat di keluarganya dan lingkungan masyarakat (Kuniarto, 2006).

Akibatnya penderita cacat kusta (PCK) cenderung hidup menyendiri dan mengurangi kegiatan sosial dengan lingkungan sekitar, tergantung kepada orang lain, merasa tertekan dan malu untuk berobat. Dari segi ekonomi, penderita kusta cenderung mengalami keterbatasan ataupun ketidakmampuan dalam bekerja maupun mendapat diskriminasi untuk mendapatkan hak dan kesempatan untuk mencari nafkah akibat keadaan penyakitnya sehingga kebutuhan hidup tidak dapat terpenuhi, apalagi mayoritas penderita kusta berasal dari kalangan ekonomi menengah ke bawah, padahal penderita kusta memerlukan perawatan lanjut sehingga memerlukan biaya perawatan. Hal - hal tersebut yang akhirnya akan mempengaruhi tingkat kualitas hidup (Kuniarto, 2006).Tujuan khusus dari penelitian ini adalah untuk menganalisis karakteristik (usia, jenis kelamin, pendidikan, pekerjaan, lama sakit) penderita kusta kecacatan tingkat 2 di UPTD Liponsos Kusta Babat Jerawat Surabaya. Untuk menganalisis bentuk dukungan emosional, dukungan penilaian,dukungan instrumental, serta dukungan informasional serta menghitung proporsi masing - masing dimensi dukungan pada penderita kusta kecacatan tingkat 2 di UPTD Liponsos Kusta Babat Jerawat Surabaya.

\section{METODE PENELITIAN}

\begin{tabular}{ccr}
\multicolumn{2}{c}{ Penelitian } & ini merupakan \\
penelitian survei & analitik dengan
\end{tabular} pendekatan cross-sectional. Penelitian ini dilaksanakan di UPTD Liponsos Kusta Babat Jerawat Surabaya. Waktu penelitian merupakan rentang waktu yang dibutuhkan untuk dilakukan penelitian.Penelitian dilakukan pada 21 Desember 2015 sampai 4 Januari 2016.

Populasi dalam penelitian ini adalah penderita kusta kecacatan tingkat 2 yang bertempat tinggal di UPTD Liponsos Kusta Babat Jerawat Surabaya sejumlah 60 penderita. Besar total sampel setelah dihitung dengan menggunakan rumus Slovin didapatkan hasil sebesar 53 orang.
Sebagai antisipasi untuk kemungkinan terjadinya sampel yang drop-out ketika pelaksanaan penelitian, maka besar sampel ditambah $10 \%$, sehingga jumlah sampel seluruhnya yang harus dipilih untuk penelitian ini sekarang totalnya 59 penderita. Namun, ketika dilakukan manajemen data, terdapat 5 responden yang tidak bersedia menjadi responden, sehingga jumlah responden yang dianalisis sebanyak 54 penderita.

Pengambilan data pada penelitian ini dilakukan dengan cara menggunakan kuesioner yang diberikan kepada masing masing penderita kusta sebagai responden penelitian. Kuesioner penelitian terdiri dari dua jenis yaitu kuesioner untuk mengkaji dukungan keluarga yang selama ini diterima atau dirasakan oleh responden dari anggota keluarganya dan kuesioner kualitas hidup yang mengkaji derajat kepuasan hati karena terpenuhinya ekternal maupun persepsinya. Pengambilan data pada penelitian ini dilakukan dengan cara mendatangi satu persatu rumah setiap responden. Pengisian kuesioner dilakukan pada saat itu dengan didampingi penanggung jawab UPTD. Pengambilan data diawali dengan penjelasan peneliti kepada penderita kusta terpilih sebagai sampel mengenai tujuan dan manfaat penelitian. Penderita kusta yang terpilih sebagai sampel mengenai tujuan dan manfaat penelitian. Penderita kusta yang bersedia menjadi responden kemudian menandatangani lembar informed consent. Pengambilan data kemudian dilakukan dengan cara responden menjawab dari beberapa pertanyaan pada masing - masing lembar kuesioner.

Kuesioner yang telah terisi selanjutnya dilakukan pengolahan data meliputi editing, coding, entry, dan cleaning. Data mengenai karakteristik responden yaitu jenis kelamin, status pernikahan, pendidikan terakhir dan pekerjaan yang diperoleh berupa data kategorik, sedangkan data usia diperoleh berupa data numerik. Data mengenai lama menderita kusta, dukungan keluarga dan data kualitas hidup diperoleh berupa data numerik. 
Hasil uji normalitas data menunjukkan bahwa data dukungan keluarga dan kualitas hidup berdistribusi normal sehingga analisa bivariat menggunakan uji statistik regresi linier. Berikut merupakan hasil penelitian berupa karakteristik responden, dukungan keluarga dan kualitas hidup penderita kusta.

\section{HASIL PENELITIAN DAN PEMBAHASAN}

\section{Karakteristik Responden}

Distribusi responden menurut usia dapat dilihat pada tabel 1 .

Tabel 1 Distribusi Responden menurut Usia pada Penderita Kusta di UPTD Liponsos Kusta Babat Jerawat Surabaya bulan Desember tahun 2015

\begin{tabular}{ccc}
\hline $\begin{array}{c}\text { Golongan Usia } \\
\text { (tahun) }\end{array}$ & $\begin{array}{c}\text { Jumlah } \\
\text { (orang) }\end{array}$ & $\begin{array}{c}\text { Persentase } \\
\text { (\%) }\end{array}$ \\
\hline $26-35$ & 1 & 1,9 \\
$36-45$ & 18 & 33,3 \\
$46-55$ & 27 & 50,0 \\
$56-65$ & 5 & 9,3 \\
$>65$ & 3 & 5,6 \\
\hline
\end{tabular}

Sumber : Data Primer, Desember 2015

Tabel 1 menunjukkan distribusi usia penderita kusta di UPTD Liponsos Kusta Babat Jerawat Surabaya. Distribusi usia responden menunjukkan bahwa persentase tertinggi pada golongan usia 46-55 tahun sebanyak 27 responden (50\%).

Distribusi responden menurut jenis kelamin, status pernikahan, pendidikan dan pekerjaan dapat dilihat pada tabel 2

Tabel 2 Distribusi Responden menurut Jenis Kelamin, Status Pernikahan, Pendidikan dan Pekerjaan

\begin{tabular}{ccc}
\hline $\begin{array}{c}\text { Karakteristik } \\
\text { Responden }\end{array}$ & $\begin{array}{c}\text { Jumlah } \\
\text { (orang) }\end{array}$ & $\begin{array}{c}\text { Persentase } \\
(\%)\end{array}$ \\
\hline Jenis kelamin & & \\
a. Laki - laki & 31 & 57,4 \\
b. Perempuan & 23 & 42,6 \\
Status Pernikahan & & \\
a. Menikah & 54 & 100 \\
Tingkat Pendidikan & & \\
a. Tidak sekolah & 9 & 16,7 \\
b. SD & 40 & 74,1 \\
c. SMP & 4 & 7,4 \\
d. SMA & 1 & 1,9 \\
\hline
\end{tabular}

\section{Jenis Pekerjaan}

a. Tidak bekerja

16,7

$\begin{array}{lll}\text { b. Swasta } & 6 & 11,1\end{array}$

c. Wiraswasta $\quad 17 \quad 31,5$

d. Petani $11 \quad 20,4$

e. IRT $11 \quad 20,4$

Sumber : Data Primer, Desember 2015

Distribusi jenis kelamin penderita kusta di UPTD Liponsos Kusta Babat Jerawat Surabaya merata di masing-masing jenis kelamin. Persentase jenis kelamin laki-laki yaitu sebesar 31 respoden $(57,4 \%)$ sedangkan persentase jenis kelamin perempuan yaitu 23 responden $(42,6 \%)$.

Tabel 2 menunjukkan distribusi status pernikahan responden menunjukkan bahwa semua responden telah menikah yaitu sebanyak 54 responden (100\%). Tingkat pendidikan menunjukkan persentase tertinggi pada jenjang pendidikan Sekolah Dasar (SD) sebanyak 40 responden $(74,1 \%)$. Distribusi pekerjaan persentase tertinggi terdapat pekerjaan wiraswasta yaitu sebesar 17 respoden $(31,5 \%)$.

\section{Analisis Dukungan Keluarga}

Variabel dukungan keluarga terdiri dari 4 indikator yaitu dukungan emosional, dukungan penilaian, dukungan instrumental, dan dukungan informasional. Distribusi responden berdasarkan dimensi dukungan keluarga dapat dilihat pada tabel 3 berikut. 
Tabel 3 Distribusi Responden menurut Dimensi Dukungan Keluarga pada Penderita Kusta di UPTD Liponsos Kusta Babat Jerawat Surabaya bulan Desember tahun 2015

\begin{tabular}{llll}
\hline & Variabel & $\mathbf{N}$ & $\mathbf{\%}$ \\
\hline Dukungan emosional & Dibawah rata - rata & 31 & 57,4 \\
& Diatas rata-rata & 23 & 42,6 \\
\hline Dukungan penilaian & Dibawah rata - rata & 27 & 50,0 \\
& Diatas rata-rata & 27 & 50,0 \\
\hline Dukungan instrumental & Dibawah rata - rata & 29 & 53,7 \\
& Diatas rata-rata & 25 & 46,3 \\
\hline Dukungan informasional & Dibawah rata - rata & 23 & 42,6 \\
& Diatas rata-rata & 31 & 57,4 \\
\hline
\end{tabular}

Sumber : Data Primer, Desember 2015

Berdasarkan Tabel 3 menunjukkan bahwa responden yang mendapatkan dukungan emosional dibawah rata - rata sebanyak 31 responden $(57,4 \%)$ dibandingkan dengan responden yang mendapatkan dukungan emosional diatas rata - rata sebanyak 23 responden $(42,6 \%)$.

Responden yang mendapatkan dukungan penilaian dibawah rata - rata dan responden yang mendapatkan dukungan penilaian diatas rata - rata yaitu sama sebanyak 27 responden (50\%).

Responden yang mendapatkan dukungan instrumental dibawah rata - rata sebanyak 29 responden $(53,7 \%)$ dibandingkan dengan responden yang mendapatkan dukungan instrumental diatas rata - rata sebanyak 25 responden $(46,3 \%)$.
Responden yang mendapatkan dukungan informasional diatas rata - rata sebanyak 31 responden $\quad(57,4 \%)$ dibandingkan dengan responden yang mendapatkan dukungan informasional dibawah rata - rata sebanyak 23 responden $(42,6 \%)$.

\section{Analisis Kualitas Hidup}

Distribusi data responden menurut kualitas hidup pada penderia kusta di UPTD Liponsos Kusta Babat Jerawat Surabaya bulan Desember tahun 2015 dapat dilihat pada tabel 4. Variabel kualitas hidup terdiri dari 4 domain yaitu kesehatan fisik, psikologis, hubungan sosial dan lingkungan. Distribusi responden berdasarkan domain kualitas hidup dapat dilihat pada tabel 4 berikut.

Tabel 4 Distribusi Responden menurut Domain Kualitas Hidup Penderita Kusta di UPTD Liponsos Kusta Babat Jerawat Surabaya bulan Desember tahun 2015

\begin{tabular}{llll}
\hline \multicolumn{2}{c}{ Domain Kualitas Hidup } & N & \% \\
\hline \multirow{2}{*}{ Kesehatan fisik } & Rendah & 34 & 63,0 \\
& Tinggi & 20 & 37,0 \\
\hline Psikologis & Rendah & 22 & 40,7 \\
& Tinggi & 32 & 59,3 \\
\hline Hubungan sosial & Rendah & 34 & 63,0 \\
& Tinggi & 20 & 37,0 \\
\hline Lingkungan & Rendah & 24 & 44,4 \\
& Tinggi & 30 & 55,6 \\
\hline
\end{tabular}

Sumber : Data Primer, Desember 2015

Berdasarkan Tabel 4 menunjukkan bahwa responden yang memiliki kesehatan fisik rendah sebanyak 34 responden $(63,0 \%)$ dibandingkan dengan responden yang memiliki kesehatan fisik tinggi sebanyak 20 responden $(37,0 \%)$.
Responden yang memiliki psikologis tinggi sebanyak 32 responden $(59,3 \%)$ dibandingkan dengan responden yang memiliki psikologis rendah sebanyak 22 responden $(40,7 \%)$.

Responden yang memiliki hubungan sosial yang rendah sebanyak 34 responden $(63,0 \%)$ dibandingkan dengan 
responden yang memiliki hubungan sosial yang tinggi sebanyak 20 responden $(37,0 \%)$.

Responden yang memiliki lingkungan yang tinggi sebanyak 30 responden $(55,6 \%)$ dibandingkan dengan responden yang memiliki lingkungan yang rendah sebanyak 24 responden $(44,4 \%)$.

\section{Analisis Hubungan Dukungan Keluarga terhadap Kualitas Hidup}

Analisis hubungan dukungan keluarga terhadap kualitas hidup penderita kusta kecacatan tingkat 2 di UPTD Liponsos Kusta Babat Jerawat Surabaya menggunakan uji statistik regresi linier karena kedua variabel merupakan data rasio dan berdistribusi normal.

Variabel independen yaitu dukungan keluarga dan 4 dimensi dukungan keluarga yaitu dukungan emosional, dukungan penghargaan, dukungan informasi dan dukungan instrumental. Sedangkan variabel dependen yaitu kualitas hidup.

Dalam penelitian ini, peneliti akan menghubungkan antara variabel bebas dan variabel terikat tanpa memperhitungkan adanya pengaruh dari variabel lain. Jika dinyatakan ada hubungan maka penentuan arah dan besarnya hubungan variabel bebas dalam memperkirakan terjadinya variabel terikat diperhitungkan dengan Odds Ratio (OR), sedangkan untuk mengetahui tingkat kemaknaan (signifikan) dilakukan perhitungan $p_{\text {value }}$ pada $a=5 \%$.

Analisis hubungan dukungan emosional, penilaian, instrumental, informasional terhadap kualitas hidup penderita kusta kecacatan tingkat 2 di UPTD Liponsos Kusta Babat Jerawat Surabaya bulan Desember 2015 dapat dilihat pada tabel 5 berikut ini

Tabel 5 Analisis Hubungan Dukungan Emosional, Penilaian, Instrumental, Informasional dengan Kualitas Hidup di UPTD Liponsos Kusta Babat Jerawat Surabaya Desember 2015

\begin{tabular}{|c|c|c|c|c|c|c|c|}
\hline \multirow{3}{*}{ Dukungan Keluarga } & \multicolumn{4}{|c|}{ Kualitas Hidup } & \multicolumn{2}{|c|}{ Total } & \multirow{3}{*}{ OR 95\% } \\
\hline & \multicolumn{2}{|c|}{ Tinggi } & \multicolumn{2}{|c|}{ Rendah } & \multirow[b]{2}{*}{$\mathbf{N}$} & \multirow[b]{2}{*}{$\%$} & \\
\hline & $\mathbf{n}$ & $\%$ & $\mathbf{N}$ & $\%$ & & & \\
\hline \multicolumn{8}{|l|}{ Dukungan Emosional } \\
\hline Diatas rata-rata & 10 & 40,0 & 15 & 51,7 & \multirow{2}{*}{54} & \multirow{2}{*}{100,0} & \multirow{2}{*}{0,000} \\
\hline Dibawah rata-rata & 15 & 60,0 & 14 & 48,3 & & & \\
\hline \multicolumn{8}{|l|}{ Dukungan Penilaian } \\
\hline Diatas rata-rata & 12 & 48,0 & 15 & 51,7 & \multirow[t]{2}{*}{54} & \multirow[t]{2}{*}{100,0} & \multirow{2}{*}{4,846} \\
\hline Dibawah rata-rata & 13 & 52,0 & 14 & 48,3 & & & \\
\hline \multicolumn{8}{|l|}{ Dukungan Instrumental } \\
\hline Diatas rata-rata & 10 & 40,0 & 15 & 51,7 & \multirow[t]{2}{*}{54} & \multirow[t]{2}{*}{100,0} & \multirow{2}{*}{1,000} \\
\hline Dibawah rata-rata & 15 & 60,0 & 14 & 48,3 & & & \\
\hline \multicolumn{8}{|l|}{ Dukungan Informasional } \\
\hline Diatas rata-rata & 2 & 8,0 & 15 & 51,7 & \multirow[t]{2}{*}{54} & \multirow[t]{2}{*}{100,0} & \multirow[t]{2}{*}{0,306} \\
\hline Dibawah rata-rata & 23 & 92,0 & 14 & 48,3 & & & \\
\hline
\end{tabular}

Sumber : Data Primer, Desember 2015

Tabel 5 menunjukkan dukungan emosional diatas rata-rata mempunyai kualitas hidup yang tinggi mempunyai persentase yang lebih kecil $(40,0 \%)$ dari dukungan emosional dibawah rata - rata $(60,0 \%)$. Dukungan penilaian diatas ratarata mempunyai kualitas hidup yang tinggi mempunyai persentase yang lebih kecil $(48,0 \%)$ dari dukungan penilaian dibawah rata - rata $(52,0 \%)$. Dukungan instrumental diatas rata-rata mempunyai kualitas hidup yang tinggi mempunyai persentase yang lebih kecil $(40,0 \%)$ dari dukungan instrumental dibawah rata - rata $(60,0 \%)$. Dukungan informasional diatas rata-rata mempunyai kualitas hidup yang tinggi mempunyai persentase yang lebih kecil $(8,0 \%)$ dari dukungan informasional dibawah rata - rata $(92,0 \%)$.

Besarnya risiko dapat dilihat dari nilai $\mathrm{OR}=4,846$ artinya penderita kusta yang mendapatkan dukungan penilaian diatas rata - rata mempunyai kemungkinan untuk mendapatkan kualitas hidup yang 
tinggi sebesar 4 kali dibandingkan dengan penderita kusta yang mendapatkan dukungan penilaian dibawah rata - rata. Besarnya risiko dilihat dari nilai $\mathrm{OR}=1,000$ artinya penderita kusta yang mendapatkan dukungan informasional diatas rata - rata mempunyai kemungkinan untuk mendapatkan kualitas hidup yang tinggi sebesar 1 kali disbandingkan dengan penderita kusta yang mendapatkan dukungan penilaian dibawah rata - rata.

\section{PEMBAHASAN}

\section{Karakteristik Responden Penderita Kusta Di UPTD Liponsos Kusta Babat Jerawat Surabaya}

Hasil karakteristik responden yang diperoleh dalam penelitian ini meliputi usia, jenis kelamin, status pernikahan, pendidikan terakhir dan pekerjaan.

Hasil penyajian data pada tabel 1 menunjukkan bahwa responden rata-rata berusia 48,89 tahun. Hasil penelitian menunjukkan bahwa usia responden adalah kelompok lansia awal. Penelitian yang dilakukan oleh Djaiman (1999) mendapatkan hasil bahwa sebanyak $84,1 \%$ penderita kusta berada pada usia produktif.

Penderita kusta akan mengalami keterbatasan fisik dalam melakukan aktivitas akibat kecacatan yang diderita, sehingga pada rentang usia tersebut akan mengurangi tingkat produktivitas. Penderita kusta yang yang berusia produktif yang mengalami kecacatan tersebut akan memberikan dampak yang negatif seperti pengangguran (Djaiman, 1999). Kahneman, Diener, \& Schwarz (1999) mengatakan bahwa pada saat kebutuhan akan hubungan dekat dengan orang lain terpenuhi, baik melalui hubungan pertemanan yang saling mendukung maupun melalui pernikahan, manusia akan memiliki kualitas hidup yang lebih baik baik secara fisik maupun emosional.

Rata-rata usia penderita kusta pada penelitian ini adalah 48,89 tahun yang tergolong dalam usia produktif sehingga beresiko untuk mengalami stress dan depresi, yang dapat mempengaruhi kualitas hidup berkurang. Usia produktif lebih beresiko untuk mengalami stress dan depresi karena memiliki tanggung jawab yang semakin meningkat terhadap diri sendiri, keluarga dan masyarakat.

Karakteristik responden yang kedua adalah jenis kelamin, dengan hasil penelitian terdapat pada tabel 2 menunjukkan bahwa dari 54 responden, sebanyak 31 responden $(57,4 \%)$ memiliki jenis kelamin laki-laki dan 23 responden $(42,6 \%)$ memiliki jenis kelamin perempuan. Hasil penelitian ini sesuai dengan Depkes RI (2006) yang menyatakan bahwa kejadian penyakit kusta pada laki-laki lebih banyak terjadi daripada wanita, kecuali di Afrika, wanita lebih banyak terkena penyakit kusta dari pada laki-laki. Laki-laki lebih banyak terpapar dengan faktor risiko terkena penyakit kusta akibat gaya hidupnya seperti halnya penyakit menular lainnya (Depkes RI, 2006). Laki-laki pada umumnya mempunyai aktivitas diluar rumah yang lebih tinggi dibandingkan dengan perempuan, sehingga laki-laki lebih rentan untuk tertular penyakit kusta (Susanto, 2006). Hasil penelitian sesuai dengan pendapat Kaur \& Van Brakel (2002) bahwa dari berbagai penelitian menunjukkan $90 \%$ dari populasi yang kontak dengan penderita akan mengalami penularan penyakit kusta.

Kejadian kusta pada perempuan lebih rendah kemungkinan dipengaruhi oleh faktor lingkungan atau biologi. Perempuan yang banyak melakukan aktivitas di dalam rumah seperti $i b u$ rumah tangga memperkecil risiko tertular penyakit kusta.

Jenis kelamin adalah salah satu fakor yang mempengaruhi kualitas hidup. Kualitas hidup perempuan cenderung lebih tinggi daripada laki - laki. Kesejahteraan laki - laki dan perempuan tidak jauh berbeda, namun perempuan lebih banyak terkait dengan aspek hubungan yang bersifat positif sedangkan kesejahteraan tinggi pada pria lebih terkait dengan aspek pendidikan dan pekerjaan yang lebih baik. Hasil penelitian ini menunjukkan jumlah penderita kusta merata antara jenis kelamin perempuan dan laki - laki.

Karakteristik responden yang ketiga adalah status pernikahan, terlihat pada tabel 2 dengah hasil penelitian menunjukkan bahwa dari 54 responden, sebagian besar 
telah menikah sebanyak 54 responden $(100 \%)$. Hasil penelitian ini sesuai dengan Pedoman nasional pemberantasan penyakit kusta menyatakan bahwa penderita kusta terbanyak adalah pada usia muda dan produktif (Depkes RI,2006). Seseorang kebanyakan menikah pada usia muda dan produktif.

Status pernikahan akan mempengaruhi seseorang individu untuk meningkatkan kualitas hidupnya. Menikah memberikan dampak lebih baik bagi kesehatan jiwa untuk semua gender (Videbeck, 2008). Seseorang yang memiliki pasangan hidup akan mendapatkan dukungan positif yang akan menguatkan individu dari segi mental ketika mengalami masalah, sehingga menurunkan resiko untuk mengalami stress dan depresi yang dapat mengakibatkan penurunan kualitas hidup. Penderita kusta yang telah menikah akan mendapatkan dukungan dari pasangan hidupnya untuk menjalani pengobatan kusta, dan mendapatkan perawatan sehingga lebih optimis untuk sembuh dari penyakit kusta. Penderita kusta yang belum menikah penting untuk mendapatkan dukungan dari anggota keluarga terdekat seperti orang tua. Orang tua mampu memberikan motivasi yang positif bagi penderita kusta untuk sembuh dari penyakit kusta. Hal ini sesuai dengan pernyataan Widayati (2005) bahwa dukungan dari orang tua dapat berupa kasih sayang, perhatian, keteladanan, bimbingan dan pengarahan, dorongan agar anak memiliki rasa percaya diri.

Karakteristik responden yang keempat adalah tingkat pendidikan. Tingkat pendidikan sebagian besar penderita kusta di UPTD Liponsos Kusta Babat Jerawat Surabaya adalah Sekolah Dasar sebanyak 40 responden $(74,1 \%)$. Pendidikan yang rendah mengakibatkan kurangnya pengetahuan penderita terhadap penyakit kusta, sehingga penderita kusta tidak memahami akibat buruk yang ditimbulkan dari penyakit kusta (Susanto, 2006). Hasil penelitian ini sesuai dengan pendapat Kaur \& Van Brakel (2002) bahwa sebagian besar (65\%) penderita kusta tidak menempuh pendidikan formal. Iyor (2005) mengatakan bahwa kejadian kusta lebih banyak terjadi pada penderita kusta yang mempunyai pengetahuan rendah. Masih rendahnya pendidikan masyarakat berakibat kurangnya informasi dan pengetahuan terhadap kesehatan.

Mantra (dalam Bayora, 2005) menyatakan bahwa tingkat pendidikan formal merupakan dasar pengetahuan intelektual yang dimiliki oleh seseorang. Hal ini berkaitan dengan pengetahuan karena semakin tinggi pengetahuan seseorang akan semakin luas wawasan yang dimiliki. Sesuai dengan konsep Broewer dalam Ikhsan (2007), faktor pendidikan seseorang sangat menentukan kecemasan, klien dengan pendidikan tinggi akan lebih mampu mengatasi masalah, menggunakan koping yang efektif dan konstruktif daripada seseorang yang berpendidikan rendah.

Hasil penelitian tentang karakteristik responden yang kelima adalah pekerjaan pada tabel 2. Sebagian besar penderita kusta memiliki pekerjaan wiraswasta sebanyak 17 responden $(31,5 \%)$. Pekerjaan seseorang akan menentukan besarnya jumlah penghasilan yang didapatkan. Penghasilan yang dimiliki oleh seseorang akan mempengaruhi terhadap status kesehatan orang tersebut. Keadaan ekonomi yang kurang mampu akan mempengaruhi akses seseorang terhadap layanan kesehatandan konsumsi pangan seseorang yang akan berpengaruh terhadap kesehatannya. Hal ini selaras dengan pernyataan Suhardjo; dalam Sarah, (2006) bahwa tingkat pendapatan keluarga sangat berpengaruh terhadap konsumsi pangan kaluarga.

Penderita kusta yang berada pada sosial ekonomi rendah akan mendapatkan stressor tambahan. Misalnya harus memikirkan penyakit kusta yang diderita, memikirkan uang untuk keluarga dan juga untuk digunakan pengobatan penyakit kusta, sehingga penderita kusta lebih beresiko untuk mengalami depresi.

\footnotetext{
Dukungan Keluarga Pada Penderita Kusta Di UPTD Liponsos Kusta Babat Jerawat Surabaya
} 
Hasil penelitian menunjukkan bahwa rata-rata nilai dukungan keluarga responden pada penderita kusta di UPTD Liponsos Kusta Babat Jerawat Surabaya sesuai dengan tabel 3 adalah 117,63. Nilai terendah variabel dukungan keluarga adalah 87, sedangkan nilai tertinggi adalah 143 . Semakin tinggi nilai yang didapat semakin baik dukungan keluarga yang diperolah penderita kusta. Dukungan keluarga termasuk dalam kategori baik jika nilai dukungan keluarga tersebut mendekati nilai tertinggi skor dukungan keluarga yaitu 143 dan dukungan keluarga termasuk dalam kategori buruk jika nilai dukungan keluarga mendekati nilai terendah skor dukungan keluarga yaitu 87 .

Hasil penelitian menunjukkan bahwa dari 54 responden yang dukungan keluarganya rendah $(<$ median $(\leq 116,50))$ sebanyak 27 responden (50\%). Sedangkan responden yang dukungan keluarganya tinggi (>median $(>116,50)$ ) sebanyak 27 responden $(50 \%)$. Jadi besar responden di UPTD Liponsos Kusta Babat Jerawat Surabaya yang didukung maupun kurang didukung yaitu sama.

Hasil penelitian tersebut tidak sesuai dengan hasil penelitian Ismi (2013) yang menunjukkan bahwa tingkat dukungan keluarga terhadap 55 responden didapatkan bahwa sebanyak 46 responden (84\%) memiliki tingkat dukungan keluarga yang baik. Hasil penelitian ini juga tidak sesuai dengan hasil penelitian Mongi (2012) yaitu penderita kusta mendapakan dukungan yang baik dari keluarga sebesar $80,1 \%$. Perbedaan hasil penelitian ini dapat disebabkan karena beberapa faktor yang dapat berasal dari keluarga maupun dari penderita kusta. Hal ini bisa disebabkan karena keluarga yang memiliki pengetahuan yang kurang tentang penyakit kusta, sehingga keluarga tidak mampu memberikan informasi dan dukungan berkaitan dengan kusta, keluarga sibuk bekerja sehingga tidak bisa memberikan perhatian dan dukungan penuh kepada penderita kusta, atau berasal dari penderita kusta yang salah mempersepsikan dukungan dari anggota keluarganya.
Dukungan keluarga adalah semua bantuan yang diberikan oleh anggota keluarga sehingga akan memberikan rasa nyaman secara fisik dan psikologis pada individu yang sedang merasa tertekan atau stress akibat masalah yang dihadapi (Taylor, 2006). Penderita kusta yang mendapatkan dukungan keluarga yang baik akan merasakan manfaat yaitu mengurangi stress dan depresi yang dirasakan karena menderita kusta sehingga kualitas hidup yang dirasakan lebih baik.

Menurut Friedman (2010), dalam suatu keluarga ada beberapa fungsi yang harus dijalankan, salah satunya adalah fungsi perawatan keluarga yaitu memberikan perawatan kepada anggota keluarga yang sakit. Proses penyembuhan pada penyakit kusta sangat dipengaruhi oleh dukungan yang diberikan oleh keluarga penderita kusta. Dukungan keluarga mempunyai peran penting dalam pengobatan, karena keluarga bisa memberikan dorongan baik fisik maupun mental bagi penderita. Dukungan keluarga yang diperoleh penderita kusta di UPTD Liponsos Kusta Babat Jerawat Surabaya berasal dari anggota keluarganya yaitu suami, istri, ayah, ibu, anak, maupun mertua. Hal ini sesuai dengan hasil penelitian Widyastuti (2009) bahwa dukungan keluarga yang dapat berasal dari sumber internal yang meliputi dukungan dari suami, istri, atau dukungan dari saudara kandung dan keluarga besar.

Dukungan keluarga yang diperoleh diharapkan mampu memberikan manfaat atau sebagai pendorong bagi penderita kusta dalam melaksanakan pengobatan rutin. Pasien kusta yang keluarganya tidak suportif akan cenderung memiliki prognosis lebih buruk, sehingga peran keluarga sangat penting karena dengan memberikan dukungan keluarga akan dapat meningkatkan kualitas hidup penderita kusta.

Dukungan keluarga terdiri dari 4 indikator yang diteliti pada penelitian ini yang meliputi dukungan informasional, dukungan penilaian, dukungan instrumental, dan dukungan emosional. 
Semua aspek dukungan keluarga tersebut saling berhubungan erat.

Hasil penelitian menunjukkan bahwa rata-rata nilai dukungan informasional responden pada penderita kusta di UPTD Liponsos Kusta Babat Jerawat Surabaya sesuai dengan tabel 4 adalah 19,39. Nilai terendah variabel dukungan informasional yaitu 12 , sedangkan nilai tertinggi adalah 24 . Semakin tinggi nilai yang didapat semakin baik dukungan informasional keluarga yang diperolah penderita kusta. Dukungan informasional termasuk dalam kategori baik jika nilai dukungan informasional tersebut mendekati nilai tertinggi skor dukungan informasional yaitu 24 dan dukungan informasional termasuk dalam kategori buruk jika nilai dukungan informasional mendekati nilai terendah skor dukungan informasional yaitu 12 .

Hasil penelitian menunjukkan bahwa dari 54 responden yang dukungan informasionalnya rendah $(<$ median $(\leq 20,00))$ sebanyak 37 responden $(68,5 \%)$. Sedangkan responden yang dukungan keluarganya tinggi $(>$ median $(>20,00))$ sebanyak 17 responden (31,5\%). Jadi sebagian besar responden di UPTD Liponsos Kusta Babat Jerawat Surabaya kurang didukung dalam dukungan informasional.

\section{Dukungan informasional}

bermanfaat dalam memberikan informasi kepada penderita kusta tentang pengobatan kusta, jadwal pengobatan, serta saran untuk merawat penyakit kusta agar tidak menjadi parah. Pemberian dukungan informasional pada penderita kusta di UPTD Liponsos Kusta Babat Jerawat Surabaya yang belum optimal dapat disebabkan oleh beberapa faktor diantaranya kurangnya informasi yang diterima keluarga mengenai penyakit kusta, keluarga kurang terampil dalam menyampaikan informasi kepada penderita kusta dan juga karena penderita sendiri yang memang tidak mau melaksanakan informasi yang diterima dari keluarga. Keluarga mendampingi penderita kusta untuk berobat serta

memperoleh penjelasan atau informasi dari petugas kesehatan terkait penyakit kusta
(Rahayu, 2012) Sehingga dalam hal ini keluarga perlu perlu mencari informasi dari media maupun dari petugas kesehatan mengenai definisi, tanda dan gejala, pengobatan dan perawatan penyakit kusta.

Dukungan yang kedua adalah dukungan penilaian. Hasil penelitian menunjukkan bahwa rata-rata nilai dukungan penilaian responden pada penderita kusta di UPTD Liponsos Kusta Babat Jerawat Surabaya sesuai dengan tabel 3 adalah 23,59. Nilai terendah variabel dukungan penilaian yaitu 18, sedangkan nilai tertinggi adalah 28. Semakin tinggi nilai yang didapat semakin baik dukungan penilaian keluarga yang diperolah penderita kusta. Dukungan penilaian termasuk dalam kategori baik jika nilai dukungan penilaian tersebut mendekati nilai tertinggi skor dukungan penilaian yaitu 28 dan dukungan penilaian termasuk dalam kategori buruk jika nilai dukungan penilaian mendekati nilai terendah skor dukungan penilaian yaitu 18.

Hasil penelitian menunjukkan bahwa dari 54 responden yang dukungan penilaiannya rendah $(<$ median $(\leq 23,50))$ sebanyak 27 responden (50\%). Sedangkan responden yang dukungan keluarganya tinggi (>median $(>23,50)$ ) sebanyak 27 responden $(50 \%)$. Jadi besar responden di UPTD Liponsos Kusta Babat Jerawat Surabaya yang didukung maupun kurang didukung dalam dukungan penilaian besar sama.

Penilaian mengacu pada kemampuan untuk menafsirkan lingkungan dansituasi diri dengan benar dan mengadaptasi suatu perilaku dan keputusan dirisecara tepat (Karyuni, 2008). Keluarga sebagai pemberi bimbingan dan umpan balik atas pencapaian anggota keluarga dengan cara memberikan support, pengakuan, penghargaan, dan perhatian sehingga dapat menimbulkan kepercayaan diri pada individu. Bantuan penilaian dapat berupa penilaian positif dan penilaian negatif yang akan berpengaruh langsung terhadap terhadap individu tersebut.

Penghargaan positif kepada penderita kusta dapat diberikan melalui ungkapan hormat, memberikan pujian saat 
penderita kusta rajin melaksanakan pengobatan, memberikan masukan untuk proses kesembuhan penyakit kusta, menghargai gagasan atau perasaan penderita kusta dan memperlakukan sama seperti orang-orang lainnya (Marlyn, 1998).

Dukungan yang ketiga adalah dukungan instrumental. Hasil penelitian menunjukkan bahwa rata-rata nilai dukungan instrumental pada penderita kusta di UPTD Liponsos Kusta Babat Jerawat Surabaya sesuai dengan tabel 3 adalah 21,46. Nilai terendah variabel dukungan instrumental yaitu 16, sedangkan nilai tertinggi adalah 28. Semakin tinggi nilai yang didapat semakin baik dukungan instrumental keluarga yang diperolah penderita kusta. Dukungan instrumental termasuk dalam kategori baik jika nilai dukungan instrumental tersebut mendekati nilai tertinggi skor dukungan instrumental yaitu 28 dan dukungan instrumental termasuk dalam kategori buruk jika nilai dukungan instrumental mendekati nilai terendah skor dukungan instrumental yaitu 16.

Hasil penelitian menunjukkan bahwa dari 54 responden yang dukungan instrumentalnya rendah $(<$ median $(\leq 21,00))$ sebanyak 29 responden $(53,7 \%)$. Sedangkan responden yang dukungan keluarganya tinggi (>median $(>21,00)$ ) sebanyak 25 responden $(46,3 \%)$. Jadi sebagian besar responden di UPTD Liponsos Kusta Babat Jerawat Surabaya kurang didukung dalam dukungan instrumental.

Keluarga menjadi sumber pemberi pertolongan secara nyata. Misalnya bantuan langsung dari orang yang diandalkan seperti memberikan materi, tenaga, dan sarana. Bantuan yang bisa diberikan diantaranya membantu memenuhi kebutuhan makan, minum, istirahat, menyediakan sarana atau alat untuk merawat penyakit kusta (Rahayu, 2012). Manfaat dari diberikannya dukungan ini yaitu individu merasa mendapat perhatian atau kepedulian dari lingkungan keluarga. Keluarga sebagai sistem pendukung bagi penderita kusta diharapkan mampu memberikan dukungan penuh dalam upaya perawatan penderita kusta.
Keluarga senantiasa mendampingi penderita kusta dalam minum obat secara teratur dan membantu memenuhi kebutuhan makan dan minum serta istirahat penderita kusta (Rahayu, 2012).

Dukungan yang keempat yaitu dukungan emosional. Hasil penelitian menunjukkan bahwa rata-rata nilai dukungan emosional pada penderita kusta di UPTD Liponsos Kusta Babat Jerawat Surabaya sesuai dengan tabel 3 adalah 53,19 . Nilai terendah variabel dukungan emosional yaitu 41, sedangkan nilai tertinggi adalah 63. Semakin tinggi nilai yang didapat semakin baik dukungan emosional keluarga yang diperolah penderita kusta. Semakin tinggi nilai yang didapat semakin baik dukungan emosional yang diperolah penderita kusta. Dukungan emosional termasuk dalam kategori baik jika nilai dukungan emosional tersebut mendekati nilai tertinggi skor dukungan emosional yaitu 41 dan dukungan emosional termasuk dalam kategori buruk jika nilai dukungan emosional mendekati nilai terendah skor dukungan emosional yaitu 63.

Hasil penelitian menunjukkan bahwa dari 54 responden yang dukungan emosionalnya rendah $(<$ median $(\leq 52,00))$ sebanyak 29 responden $(53,7 \%)$. Sedangkan responden yang dukungan keluarganya tinggi (>median $(>52,00)$ ) sebanyak 25 responden (46,3\%). Jadi sebagian besar responden di UPTD Liponsos Kusta Babat Jerawat Surabaya kurang didukung dalam dukungan emosional.

Dukungan emosional yang diberikan berupa rasa empati dan perhatian kepada individu, sehingga membuatnya merasa lebih baik, mendapatkan kembali keyakinannya, merasa dimiliki dan dicintai oleh orang lain (Sarafino, 2004). Sehinggan dalam hal ini keluarga memberikan dukungan emisosnal yang berupa perhatian kepada penderita kusta sehingga penderita merasa nyaman, dicintai dan diperhatikan. Menurut Nugroho (2000), dukungan emosional merupakan suatu bentuk dukungan berupa rasa aman, cinta kasih, memberi semangat, mengurangi putus asa 
dan rendah diri sebagai akibat dari ketidakmampuan fisik. Dukungan emosional dalam keluarga akan mempengaruhi pertumbuhan dan perkembangan anggota keluarga (Friedman, 2010). Dukungan emosional untuk penderita kusta misalnya melalui ungkapan empati, kepedulian dan perhatian untuk mengobati penyakit kusta yang dideritanya (Marlyn, 1998).

\section{Kualitas Hidup Penderita Kusta di UPTD Liponsos Kusta Babat Jerawat Surabaya}

Hasil penelitian menunjukkan bahwa rata - rata nilai kualitas hidup penderita kusta di UPTD Liponsos Kusta Babat Jerawat Surabaya sesuai dengan tabel adalah 199,61. Nilai terendah kualitas hidup penderita kusta adalah 151, sedangkan nilai tertinggi adalah 251. Semakin rendah nilai yang didapat semakin rendah kualitas hidup penderita kusta yang dialami. Kualitas hidup termasuk dalam kategori berat jika nilai kualitas hidup tersebut mendekati nilai tertinggi skor kualitas hidup yaitu 251 dan kualitas hidup termasuk dalam kategori ringan jika nilai kualitas hidup mendekati nilai terendah skor kualitas hidup yaitu 151 . Peneliti menganalisis bahwa nilai rata-rata kualitas hidup penderita kusta di UPTD Liponsos Kusta Babat Jerawat Surabaya $(199,61)$ lebih mendekati nilai tengah antara nilai terendah dan tertinggi. Hal ini menunjukkan bahwa penderita kusta di UPTD Liponsos Kusta Babat Jerawat Surabaya memiliki kualitas hidup sedang.

Penelitian yang dilakukan oleh Tsutsumi et al., (2003) di Bangladesh, menunjukan hasil bahwa faktor - faktor yang berkontribusi terhadap penurunan skor kualitas hidup adalah adanya perceive stigma, lama (tahun) pendidikan, adanya kecacatan kusta dan penghasilan rendah. Hasil dari penelitian tersebut menyebutkan bahwa penyebab kualitas hidup menurun pada penderita kusta yaitu penderita kusta mendapat hinaan secara fisik oleh masyarakat, penderita kusta merasa bahwa dirinya aneh bagi masyarakat, dan adanya stigma yang negatif dari masyarakat. Masyarakat beranggapan bahwa penyakit kusta merupakan penyakit menular yang berbahaya, penyakit keturunan, penyakit kutukan, sehingga masyarakat merasa jijik dan takut pada penderita kusta terutama yang mengalami kecacatan (Depkes, 2006).

Upaya yang dapat dilakukan perawat untuk membantu keluarga dalam merawat anggota yang menderita kusta antara lain keluarga ikut serta dalam merawat penderita kusta, meningkatkan hygiene sanitasi lingkungan sekitar, memotivator anggota keluarga yang menderita kusta sehingga penderita kusta merasa nyaman, aman dan percaya diri sehingga dapat meningkatkan kualitas hidup penderita kusta.

\section{Hubungan Dukungan Keluarga dengan Kualitas Hidup Pada Penderita Kusta Di UPTD Liponsos Kusta Babat Jerawat Surabaya}

Hasil uji statistik dengan menggunakan uji regresi linier yang terlihat pada tabel 5 menunjukkan p value $(0,001)<$ $(0,05)$ yang berarti hipotesis penelitian diterima yaitu ada hubungan yang signifikan antara dukungan keluarga terhadap kualitas hidup penderita kusta kecacatan tingkat 2 di UPTD Liponsos Kusta Babat Jerawat Surabaya. Hal ini didukung dengan kekuatan korelasi yang diperoleh sebesar $(\mathrm{r}=0,431)$ yang menunjukkan ada hubungan yang lemah antara dukungan keluarga terhadap kualitas hidup dan nilai korelasi memiliki arah positif artinya semakin besar dukungan keluarga maka semakin baik kualitas hidup yang dialami oleh penderita kusta kecacatan tingkat 2.

Berdasarkan nilai rata - rata dan disesuaikan dengan skala instrument pada penelitian ini, dapat disimpulkan bahwa responden sering mendapatkan dukungan dari keluarga, baik dari segi emosional, penghargaan, instrumental dan informasi.

Berdasarkan hasil penelitian,
didapatkan bahwa faktor dukungan keluarga berpengaruh terhadap kualitas hidup. Kualitas hidup adalah kapasitas fungsional, psikologis dan kesehatan social serta kesejahteraan individu. Kualitas hidup mempengaruhi kesehatan fisik, kondisi psikologis, tingkat ketergantungan, hubungan social dan hubungan pasien 
dengan lingkungan sekitarnya (Skevington SM et al 2006). Beberapa literatur menyatakan bahwa dukungan keluarga berperan penting dalam meningkatkan kualitas hidup penderita kusta. Dukungan keluarga yang diberikan kepada penderita kusta dapat berbentuk dukungan emosional, penghargaan, instrumental dan informasi.

Berdasarkan hasil tabulasi silang didapatkan bahwa dimensi dukungan keluarga yaitu dukungan emosional dibawah rata - rata yang mempengaruhi tinggi rendahnya kualitas hidup penderita kusta. Dapat diartikan bahwa dukungan emosional yang tinggi dapat menghasilkan kualitas hidup yang tinggi. Dukungan emosional yang rendah dapat menghasilkan kualitas hidup yang rendah.

Salah satu fungsi keluarga adalah fungsi afektif, fungsi keluarga yang berhubungan dengan fungsi internal keluarga dalam memberikan perlindungan psikososial dan dukungan terhadap anggota keluarga. Keluarga sebagai sumber cinta, pengakuan, penghargaan, dan sumber dukungan primer. Friedman, 2010 menjelaskan bahwa fungsi afektif keluarga merupakan aspek dasar dalam pembentukan dan tercapainya keharmonisan keluarga. Kasih sayang serta pengakuan dari anggota keluarga akan memberikan perasaan yang nyaman dan meningkatnya harga diri pada penderita kusta.

Dukungan emosional untuk penderita kusta misalnya melalui ungkapan empati, kepedulian dan perhatian untuk mengobati penyakit kusta yang dideritanya (Marlyn, 1998). Dukungan emosional yang diberikan berupa rasa empati dan perhatian kepada individu, sehingga membuatnya merasa lebih baik, mendapatkan kembali keyakinannya, merasa dimiliki dan dicintai oleh orang lain (Sarafino, 2004). Sehingga dalam hal ini keluarga memberikan dukungan emisonal yang berupa perhatian kepada penderita kusta sehingga penderita merasa nyaman, dicintai dan diperhatikan. Menurut Nugroho (2000), dukungan emosional merupakan suatu bentuk dukungan berupa rasa aman, cinta kasih, memberi semangat, mengurangi putus asa dan rendah diri sebagai akibat dari ketidakmampuan fisik. Dukungan emosional dalam keluarga akan mempengaruhi pertumbuhan dan perkembangan anggota keluarga (Friedman, 2010).

\section{SIMPULAN DAN SARAN}

\section{Simpulan}

Kesimpulan yang dapat diambil dari hasil penelitian dan pembahasan tentang hubungan dukungan keluarga terhadap kualitas hidup penderita kusta kecacatan tingkat 2 di UPTD Liponsos Kusta Babat Jerawat Surabaya yang dilakukan pada tanggal 21 Desember 2015 sampai 4 Januari 2016 adalah penderita kusta ratarata berusia 49 tahun, lebih banyak jenis kelamin laki-laki $(57,4 \%)$, seluruhnya telah menikah (100\%), sebagian besar pendidikan sekolah dasar $(74,1 \%)$, sebagian besar bekerja wiraswasta $(31,5 \%)$ dan ratarata menderita kusta selama 13 tahun.

Bentuk dukungan emosional yang diberikan pada penderita kusta meliputi rasa empati, perhatian, cinta dan kepercayaan. Rata-rata nilai dukungan emosional responden pada penderita kusta kecacatan tingkat 2 di UPTD Liponsos Kusta Babat Jerawat Surabaya adalah 53,19.

Bentuk dukungan penilaian yang diberikan pada penderita kusta meliputi penilaian positif, support dan bimbingan. Rata-rata nilai dukungan penilaian responden pada penderita kusta kecacatan tingkat 2 di UPTD Liponsos Kusta Babat Jerawat Surabaya adalah 23,59.

Bentuk dukungan instrumental yang diberikan pada penderita kusta meliputi bantuan materi, tenaga dan sarana. Ratarata nilai dukungan instrumental responden pada penderita kusta kecacatan tingkat 2 di UPTD Liponsos Kusta Babat Jerawat Surabaya adalah 21,46.

Bentuk dukungan informasional yang diberikan pada penderita kusta meliputi nasihat, informasi dan bimbingan. Rata-rata nilai dukungan penilaian responden pada penderita kusta kecacatan tingkat 2 di UPTD Liponsos Kusta Babat Jerawat Surabaya adalah 19,39.

Ada hubungan yang signifikan antara dukungan keluarga terhadap kualitas hidup 
penderita kusta kecacatan tingkat 2 di UPTD Liponsos Kusta Babat Jerawat Surabaya.

\section{Saran}

Saran yang dapat diberikan adalah dukungan keluarga yang meliputi dukungan instrumental, informasi, emosional, dan penilaian sebaiknya dapat lebih ditingkatkan. Anggota keluarga penderita kusta dan masyarakat sekitar hendaknya meningkatkan dukungannya terhadap penderita kusta agar kualitas hidup penderita kusta baik. Hal penting lainnya yang sebaiknya dilakukan oleh keluarga yaitu meningkatkan kedekatan emosional dengan penderita kusta sehingga kejadian stress dan depresi pada penderita kusta dapat diatasi.

$$
\begin{aligned}
& \text { Masyarakat memberi dukungan } \\
& \text { kepada anggota keluarga } r \text { untuk } \\
& \text { meningkatkan dukungannya terhadap } \\
& \text { penderita kusta. Masyarakat juga } \\
& \text { memberikan perhatian, empati kepada } \\
& \text { penderita kusta sehingga penderita kusta } \\
& \text { tidak merasa didiskriminasikan dari } \\
& \text { lingkungan sekitar. }
\end{aligned}
$$

\section{REFERENSI}

Amiruddin, M. Dali. Penyakit Kusta di Indonesia; Masalah Penanggulangannya. [Online] Available at :http://med.unhas.ac.id/index.php?optio $\mathrm{n}=\mathrm{com}$ content\&task $=$ view\&id $=235 \& \mathrm{I}$ temid $=\overline{9} 1$. [20 Agustus 2015).

Bakrie, Iskandar.Penderita Kusta. [Online] Available at :http://www.tnol.co.id/bugar/1485memberikansemangathidupmerupakan-obatmujarab-penderita-kusta.html.[20 Agustus 2015].

Brouwers, et. al. Quality Of Life, Perceived Stigma, Activity And Participation Of People With Leprosy-Related Disabilities In South-EastNepal. [Online] Available at : http://dcidj.org/article/download/15/30. [18 Agustus 2015].

Budiarto. 2004. Metodologi Penelitian Kedokteran. Jakarta :EGC.
Burns, et al. 2010. Rook's Textbook of Dermatology Eight Edition. United Kingdom: Wiley-Blackwell.

Chin, James. 2006. Manual Pemberatasan Penyakit Menular. Jakarta: Infomedika.

Depkes RI. 2006. Buku Pedoman Nasional Pemberantasan Penyakit Kusta. Jakarta: Direktorat Jenderal Pengendalian Penyakit dan Penyehatan Lingkungan.

Dinkes Provinsi Jawa Timur. 2014. Profil Kesehatan Provinsi Jawa Timur 2013. Surabaya

Friedman, M. 2010. Buku Ajar Keperawatan Keluarga: Riset, teori, dan praktik Ed 5. Jakarta: EGC

Kemenkes RI. 2014. Profil Kesehatan Indonesia Tahun 2013. Jakarta.

Matulessy, Andik. Penderita Kusta Juga Manusia (Biasa). [Online] Available at : $\quad \mathrm{http}: / /$ psikologipolitik.blogspot.com/2010/11/penderita -kusta-jugamanusia-biasa.html.[12 September2015].

Noto, S. \& Schreuder, P. A. Diagnosis of Leprosy. [Online] Available at :

http://www.ilep.org.uk/fileadmin/uploads/ Documents/NonILEP_Publications/Do LText.pdf.[12September 2015].

Notoatmodjo. 2012. Metodologi Penelitian Kesehatan. Jakarta : Rineka Cipta.

Rao, S. \& Joseph, G. Impact Of Leprosy On The Quality Of Life. [Online] Available at

http://www.who.int/bulletin/archives/7 7\%286\%29515.pdf. [25 Agustus 2015].

Seksi P2 Dinkes Provinsi Jawa Timur. 2012. Data Kasus Kusta menurut Kabupaten/Kota tahun 2014. Surabaya : Dinkes Provinsi Jawa Timur.

Setiadi. 2007. Konsep dan Penulisan Riset Keperawatan. Jakarta : Graha Ilmu.

Susanto, Nugroho. 2006. Faktor-Faktor yang Berhubungan Dengan Tingkat Kecacatan Penderita Kusta (Kajian di Kabupaten Sukoharjo). Tesis. Yogyakarta: Sekolah Pascasarjana Universitas Gadjah Mada.

World Health Organization (WHO). Leprosy. [Online] Available at : http://www.who.int/mediacentre/factsh 
Hubungan Dukungan Keluarga Terhadap Kualitas Hidup Penderita Kusta.. | ANDINTA REFITLIANTI eets/fs 101/en/index.html. [25 Agustus 2015].

Zulkifli.2003. Penyakit kusta dan masalah yang ditimbulkannya. Dipublikasikan oleh USU Digital Library. 
JURNAL ILMIAH KESEHATAN MEDIAHUSADA ｜ＶOLUME 06/NOMOR 02/OKTOBER 2017 